\title{
Sistem Informasi Geografis Pemetaan Titik Rest Area Pada Jalan Poros Jalur Samarinda - Penajam Paser Utara Berbasis Web
}

\author{
Ronaldo Pascalis Naro ${ }^{1)}$, Wahyuni Eka Sari* 2), Syafei Karim ${ }^{3)}$ \\ ${ }^{1,3)}$ Teknologi Rekayasa Perangkat Lunak, Politeknik Pertanian Negeri Samarinda-Samarinda \\ ${ }^{2}$ Teknologi Rekayasa Komputer, Politeknik Negeri Samarinda-Samarinda \\ Ronalpascalis@gmail.com ${ }^{1)}$, wahyunisari52@gmail.com ${ }^{2}$, syfei.karim@gmail.com $^{3)}$
}

\begin{abstract}
Abstrak--Penelitian ini dilatarbelakangi oleh minimnya informasi rest-area dalam hal penunjang mobilitas seperti saat berpergian atau berlibur, keperluan bisnis, perjalanan studi, dan mobilitas seperti pengiriman logistik dari Samarinda ke Penajam Paser Utara. Hal ini dikarenakan jarak antara kedua kota yang cukup jauh, seperti informasi lokasi tempat yang akan digunakan pengendara saat melewati jalan raya seperti rest area, restoran, hotel, pompa bensin umum (SPBU), rumah ibadah dan juga toko-toko kecil yang seharusnya berfungsi sebagai tempat peristirahatan. Oleh karena itu, dalam penelitian ini dibangun sistem informasi geografis untuk pemetaan rest-area point Jalan Samarinda hingga Penajam Paser Utara. Pengambilan data menggunakan Google Maps API, wawancara, pengumpulan data titik-titik koordinat dan beberapa data pendukung lainnya. Aplikasi berbasis web ini telah diujicobakan kepada 30 pengguna dengan tanggapan setuju bahwa aplikasi tersebut berjalan sesuai fungsinya.
\end{abstract}

Kata-kata Kunci - GIS, Rest Area, Samarinda - Penajam Paser Utara

\section{PENDAHULUAN}

Samarinda adalah Ibukota Provinsi Kalimantan Timur dengan luas wilayah yang cukup besar dan memiliki penduduk 872.768 jiwa (Badan Pusat Statistika, 2018) dan Penajam Paser Utara adalah sebuah kabupaten yang juga berada provinsi Kalimantan Timur yang memiliki cangkupan wilayah dengan luas 3.333,06 $\mathrm{km}^{2}$ dan dengan jumlah penduduk mencapai 159.386 jiwa. Sementara itu recana pemindahan Ibukota Negara ke Kabupaten Penajam Paser Utara dan sebagian di Kabupaten Kutai Kartanegara yang secara tidak langsung akan membuat padatnya penduduk secara umum di provinsi Kalimantan Timur. Kepadatan penduduk pada 2 kota tersebut pun tentunya mempengaruhi tingkat jumlah kendaraan yang dimiliki masyarakat sampai saat ini tercatat data kendaraan bermotor di Kota Samarinda mencapai 683.420 unit (Badan Pusat Statistika Provinsi Kaltim 2015) dan di Kabupaten Penajam Paser Utara mencapai 75.702 unit (Badan Pusat Statistik Kabupaten Penajam Paser Utara 2018).

Jarak antara Kota Samarinda dan Kabupaten Penajam Paser Utara sekitar 170,3 km, dengan

waktu tempuh sekitar 4 jam menggunakan kendaraan bermotor melewati jalan poros jalur Samarinda - Penajam Paser Utara jarak dan waktu tempuh tersebut jika menggunakan transportasi laut yaitu kapal ferry di Pelabuhan Ferry Kariangau, Kota Balikpapan. Akses jalur darat yang buruk dan tentunya akan membtuhkan banyak waktu karena jaraknya yang cukup jauh, jalur ini juga merupakan jalur utama atau jalur provinsi yang menghubungkan kota lain seperti Balikpapan, Tenggarong, dan Bontang ke kota atau kabupaten lain seperti Paser dan Tanah Grogot bahkan Banjarmasin, dalam hal pendukung mobilitas masyarakat seperti saat berpergian melakukan perjalanan wisata atau berlibur, keperluan bisnis, perjalan studi, atau mobilitas seperti pengiriman logistik dari Samarinda ke Kabupaten Penajam Paser Utara atau sebaliknya tentunya diperlukan sarana dan prasarana yang mendukung terutama karena jarak tempuh antar kedua kota ini cukup jauh, seperti informasi lokasi tempat yang akan digunakan oleh pengendara saat melewati jalan poros tersebut seperti tempat peristirahatan, rumah makan, hotel, Stasiun Pengisian Bahan Bakar Umum (SPBU), rumah ibadah dan juga warung kecil yang seharusnya bisa dijadikan tempat peristirahatan.

Tujuan dari penelitian ini untuk merancang dan membangun suatu sistem informasi geografis mengenai peta pesebaran titik tempat peristirahatan pada jalan poros jalur Samarinda - Penajam Paser Utara beserta informasi secara detail mengenai tempat tersebut berbasis web.

\section{METODOLOGI PENELITIAN}

A. Waktu dan Tempat

Penelitian ini dilakukan di jalan poros jalur Kota Samarinda menuju Kabupaten Penajam Paser Utara yang melewati penyeberangan Fery Kariangau, Kota Balikpapan. Dilaksanakan selama 6 (enam) bulan terhitung dari bulan Oktober 2019 hingga Maret 2020.

B. Alat dan Bahan 
Pengembangan sistem informasi ini menggunakan alat dan bahan sebagai berikut: 1. Spesifikasi hardware yang digunakan dalam pengembangan sistem ini adalah sebagai berikut:

a. Laptop Acer Aspire e1-471g

b. Processor Core i3-2348M @ 2,3 Ghz

c. RAM 4GB

d. HDD 1 TB

e. HP VIVO Y83

f. Printer

2. Spesifikasi Software yang digunakan dalam pengembangan sistem ini adalah sebagai berikut:

a. Sistem Operasi Windows 10

b. Google Maps API

c. Aplikasi My GPS Coordinates

d. Sublime Text3

3. Bahan yang digunakan adalah data latitude dan longitude Rest Area

\section{Prosedur Penelitian}

Tahapan pembuatan aplikasi Sistem Informasi Geografis Pemetaan titik rest area pada jalan poros jalur Samarinda - Penajam Paser Utara Berbasis Web digunakan. Model ini melakukan pendekatan secara sistematis atau secara berurutan, dalam membangun suatu alur prosedur penelitian ini di tunjukan pada Gambar 1.

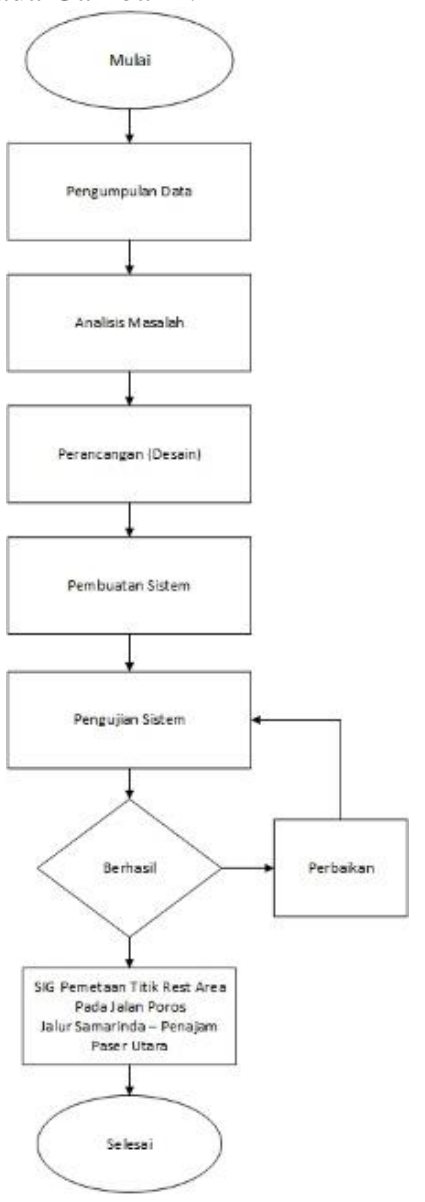

Gambar 1. Diagram Alir Prosedur Penelitian

\section{Teknik Pengambilan Data}

Berikut merupakan Diagram dari alur teknik pengambilan data dalam pembuatan aplikasi, lihat pada Gambar 2.

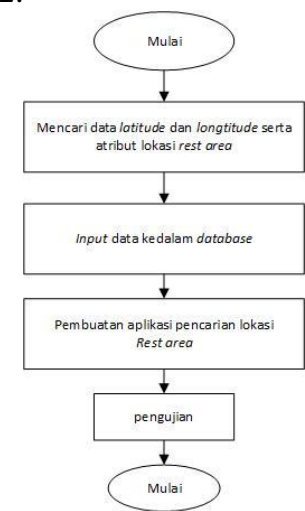

Gambar 2. Diagram Alir Teknik Pengambilan Data

1. Mencari Data Latitude dan Longtitude

Latitude dang Longtitude pada umumnya digunakan untuk mengukur jarak antara satu titik dengan titik lain. Karena titik koordinat menjadi kunci utama saat membaca Google Maps.

2. Input data ke Database

Data yang sudah ada dimasukan kedalam database, data tersebut berupa data lokasi titik rest area berada dan atribut lain seperti informasi nama tempat, alamat dan fasilitas yang ada.

3. Membuat Aplikasi

Pada tahap ini dimulailah pembuatan aplikasi yang terdiri dari pembuatan aplikasi dan pengujian internal

\section{Pengujian}

Pada tahap ini dilakukan proses pengujian sistem untuk mengetahui apakah sistem bekerja atau tidak.

\section{E. Rancangan Sistem}

1. DFD level 0

Admin dapat login dan mengelola data dan pengguna bisa mendapatkan informasi detail tentang lokasi rest area. Berikut ini adalah DFD (Data Flow Diagram) level 0, dapat dilihat pada Gambar 3.

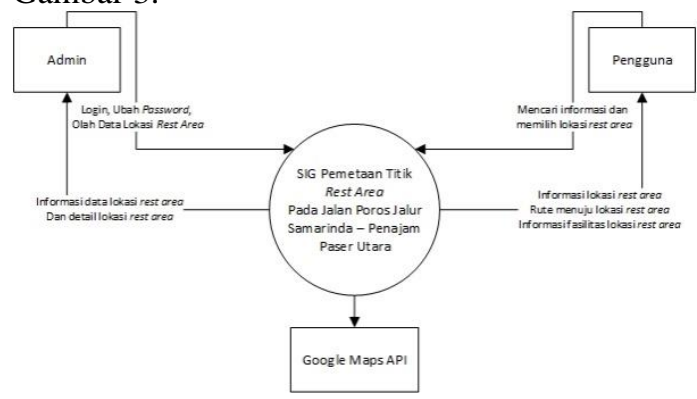

Gambar 3. Tahapan Pembuatan DFD Level 0 
Naro, dkk., Sistem Informasi Geografis Pemetaan Titik Rest Area pada Jalan Poros Jalur Samarinda - Penajam Paser Utara Berbasis Web

\section{DFD level 1}

Admin dapat login untuk masuk ke aplikasi dan mengelola data seperti edit data, tambah data dan hapus data. Aplikasi ini juga memberikan informasi seperti nama, alamat lokasi rest area, fasilitas, dan informasi lain, pengguna mencari tentang informasi lokasi rest area juga rute menuju lokasi tesebut, dan aplikasi sistem informasi geografis ini memberikan informasi kepada pengguna. Berikut ini adalah DFD (Data Flow Diagram) level 1, dapat dilihat pada Gambar 4.

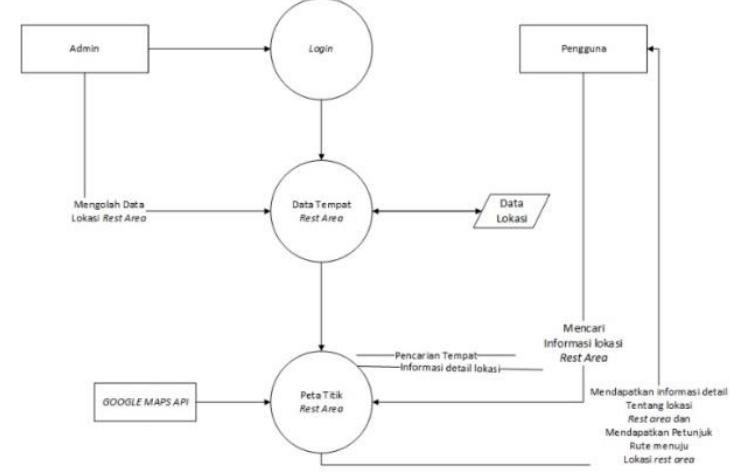

Gambar 4. Tahapan Pembuatan DFD Level 1

\section{F. Rancangan Database}

Rancangan Database dari penelitian ini dapat dilihat pada tabel-tabel berikut:

Tabel 1. Merupakan tabel tempat yang berisi informasi data spasial dan non spasial, data spasial digunakan untuk menampilkan peta titik rest area dan data non spasial digunakan untuk memberikan informasi tentang titik rest area.

Tabel 1. Tabel_Tempat

\begin{tabular}{llll}
\hline Nama Fields & Tipe Data & Panjang & Keterangan \\
\hline id_tempat & INT & 11 & PK \\
nama_tempat & Varchar & 255 & \\
lokasi & Varchar & 255 & \\
gambar & Varchar & 255 & \\
lat & Double & & \\
lng & Double & & \\
fasilitas & Text & & \\
keterangan & Text & & \\
kategori & Varchar & 50 & \\
\hline
\end{tabular}

Tabel 2. Merupakan tabel user yang berisi informasi yang digunakan admin untuk bisa login dengan menggunakan username dan password.

Tabel 2. Tabel_User

\begin{tabular}{llll}
\hline \multicolumn{3}{c}{ Tabel 2. Tabel_User } & \\
\hline Nama Fields & $\begin{array}{l}\text { Tipe } \\
\text { Data }\end{array}$ & Panjang & Keterangan \\
\hline id_admin & INT & 11 & PK \\
Admin & Varchar & 255 & \\
Pass & Varchar & 255 & \\
\hline
\end{tabular}

Pada Tabel 3 adalah tabel album berisi foto-foto mengenai lokasi rest area.

Tabel 3. Tabel_Album

\begin{tabular}{llll}
\hline Nama Fields & Tipe Data & Panjang & Keterangan \\
\hline id & INT & 11 & PK \\
id_tempat & INT & 11 & FK \\
galeri & Varchar & 255 & \\
\hline
\end{tabular}

Tabel 4. Berisi info berisi data untuk menampilkan gambar dan informasi pada halaman depan web

\begin{tabular}{cccc}
\multicolumn{4}{c}{ Tabel 4. Tabel_Info } \\
\hline Nama & Tipe & Panjang & Keterangan \\
Fields & Data & & \\
\hline id_info & INT & 11 & PK \\
nama & Varchar & 50 & \\
gambar & Varchar & 50 & \\
info & Text & & \\
\hline
\end{tabular}

Tabel 5. Berisi tabel options, merupakan data untuk menentukan titik pusat pada peta.

\begin{tabular}{llll}
\multicolumn{4}{c}{ Tabel 5.Tabel_Options } \\
\hline Nama Fields & Tipe Data & Panjang & Keterangan \\
\hline option_name & Varchar & 16 & \\
option_value & Text & & \\
\hline
\end{tabular}

\section{HASIL DAN PEMBAHASAN}

\section{Hasil}

Hasil dari pembuatan aplikasi ini adalah menampilkan hasil dari pembuatan aplikasi sistem informasi geografis titik rest area pada jalan poros jalur Samarinda - Penajam Paser Utara berbasis WEB berdasarkan rancangan yang telah dibuat sebelumya. Hasil pembuatan aplikasi adalah sebagai berikut:

\section{a. Tampilan Utama}

Pada halaman utama menampilkan penjelasan tentang fungsi sistem ini, dan menampilkan beberapa tempat yang biasa digunakan sebagai lokasi peristirahatan. Hasil dari implementasi halaman tampilan utama disajikan pada Gambar 5.

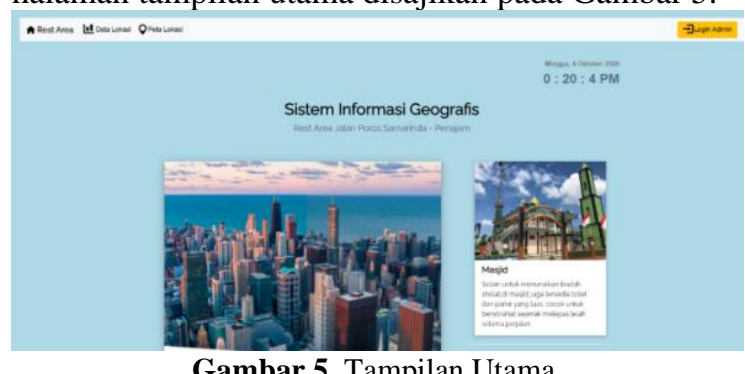

b. Tampilan Maps 
Pada halaman maps menampilkan peta dengan titik rest area yang telah di input dan terdapat juga button pencarian. Hasil dari implementasi halaman tampilan peta dapat dilihat pada Gambar 6 .

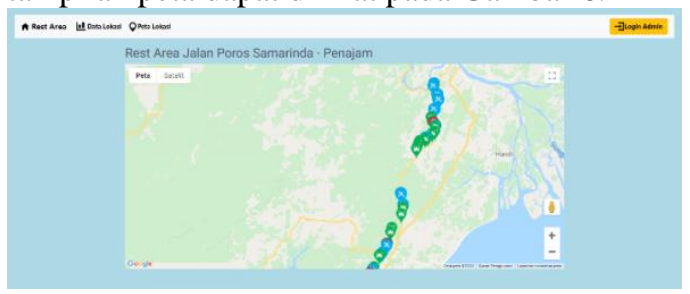

Gambar 6. Tampilan Maps

Pada halaman ini, pengguna dapat memilih salah satu titik rest area untuk melihat informasi detail lokasi rest area dengan cara memencet tombol pada icon marker titik rest area dan akan muncul dalam bentuk jendela (info window) kemudian klik button lihat detail. Hasil dari implementasi halaman info window dapat dilihat pada Gambar 7.

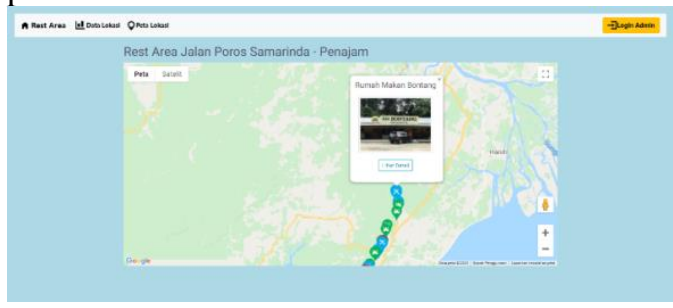

Gambar 7. Tampilan Info Window

c. Tampilan Informasi Detail Lokasi

Halaman info detail pada gambar 20 menampilkan lokasi yang telah dipilih sebelumnya, info detail memberikan informasi seperti nama tempat, alamat, jam buka, estimasi harga, fasilitas, dan infromasi lainnya. Pada halaman ini terdapat juga button untuk kembali ke peta, tampilkan rute, dan rute detail.

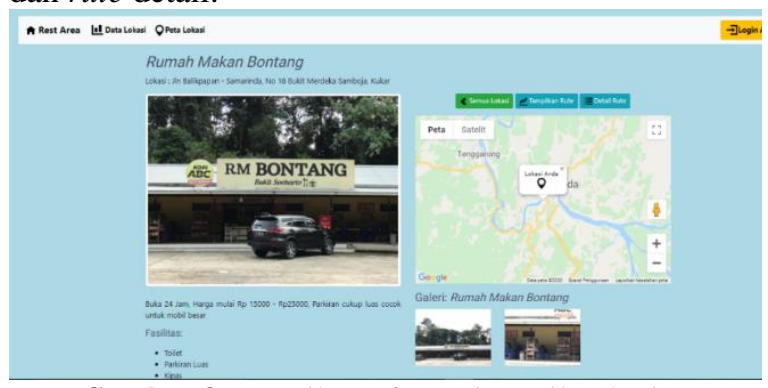

Gambar 8. Tampilan Informasi Detail Lokasi

\section{d. Tampilan Rute}

Halaman ini menampilkan rute dari titik pengguna ke titik yang akan dituju. Hasil dari implementasi halaman yang menunjukan rute dapat dilihat pada Gambar 9.

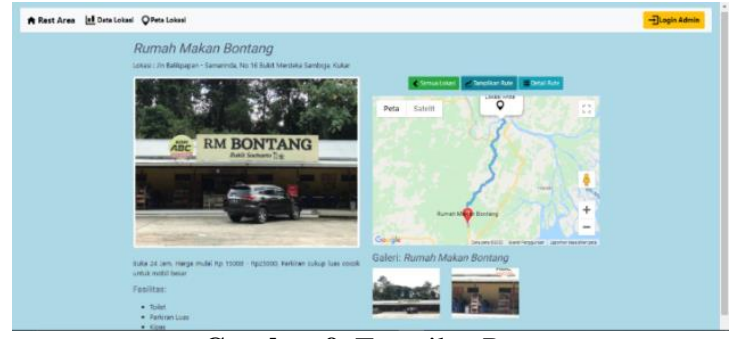

Gambar 9. Tampilan Rute

e. Tampilan Detail Rute Lokasi Rest Area

Halaman ini menampilkan rute detail dari titik pengguna ke titik yang akan dituju. Informasi detail menampilkan dua jalur menuju ke titik yang dituju. Pada halaman ini terdapat button untuk kembali ke halaman informasi detail lokasi rest area. Hasil dari implementasi tampilan halaman detail rute lokasi rest area disajikan pada Gambar 10.

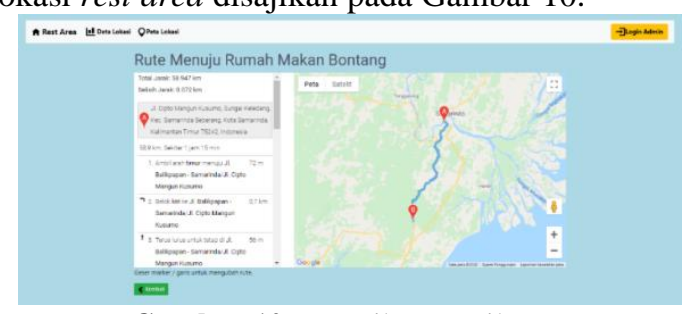

Gambar 10. Tampilan Detail Rute

f. Tampilan Data Lokasi Untuk User

Halaman ini memberikan informasi tentang data lokasi rest area secara keseluruhan dan user dapat dengan mudah memilih lokasi rest area yang ingin dikunjungi. Hasil dari implementasi tampilan halaman data lokasi detail lokasi untuk user dapat dilihat pada Gambar 11.

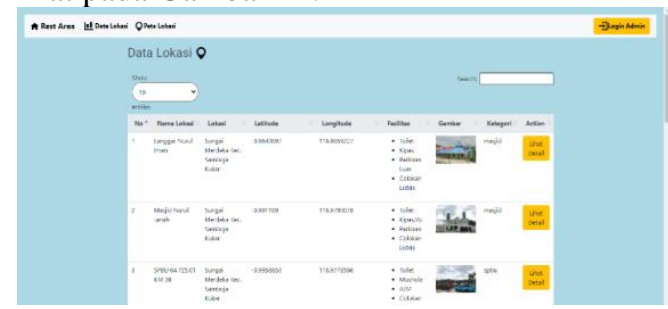

Gambar 11. Tampilan Data Lokasi User

\section{g. Tampilan Login Admin}

Halaman ini menampilkan form username dan password untuk admin agar dapat masuk ke sistem dan mengakses data. Hasil dari implementasi tampilan halaman login admin ditunjukan pada Gambar 12.

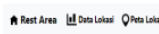

Gambar 12. Tampilan Login Admin 
Naro, dkk., Sistem Informasi Geografis Pemetaan Titik Rest Area pada Jalan Poros Jalur Samarinda - Penajam Paser Utara Berbasis Web

h. Tampilan Data Lokasi Rest Area Admin

Halaman data lokasi rest area menampilkan tabel yang memberikan informasi lengakap rest area. Pada halaman ini juga terdapat button pencarian dan tambah data, selain itu terdapat juga dua aksi yaitu edit dan hapus data. Hasil dari implementasi tampilan halaman data lokasi rest area disajikan pada Gambar 13.

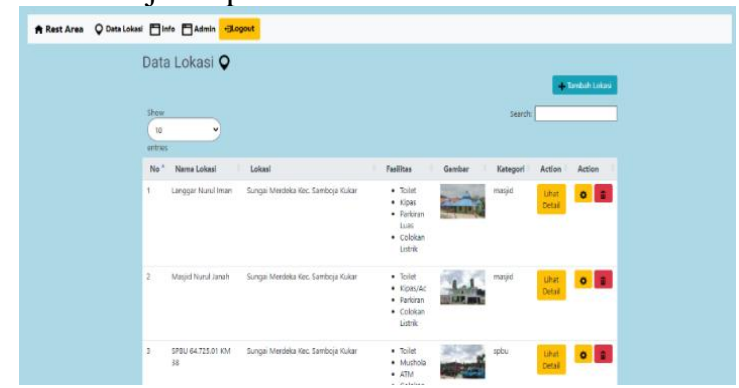

Gambar 13. Tampilan Data Lokasi Admin

i. Tampilan Tambah Data Lokasi Rest Area

Halaman tambah data menampilkan form untuk menginput data lokasi rest area baru dan pada halaman ini terdapat button simpan dan kembali. Hasil dari implementasi tampilan halaman tambah data lokasi disajikan dapat dilihat pada Gambar 14.

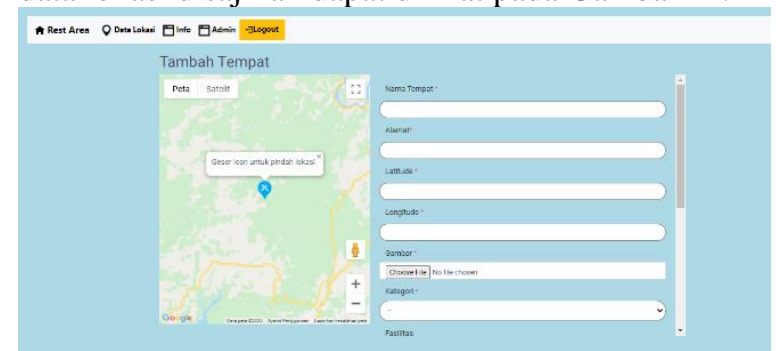

Gambar 14. Tampilan Tambah Data Lokasi Rest Area j. Tampilan Detail Tempat Admin

Halaman info detail admin pada Gambar 15. Menampilkan lokasi yang telah dipilih sebelumnya, info detail memberikan informasi seperti nama tempat, alamat, jam buka, estimasi harga, fasilitas, dan infromasi lainnya. Pada halaman ini terdapat juga button tambah data foto dan lihat album

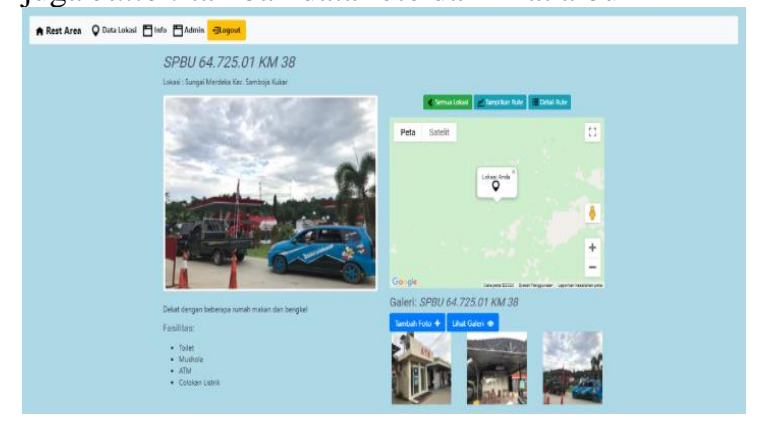

Gambar 15. Tampilan Detail Tempat Admin

k. Tampilan Ubah Sandi Admin

Halaman ubah sandi admin menampilkan form untuk mengubah data sandi admin, sandi ini diperlukan untuk dapat login ke aplikasi. Hasil dari implementasi tampilan halaman ubah sandi admin dapat dilihat pada Gambar 16.

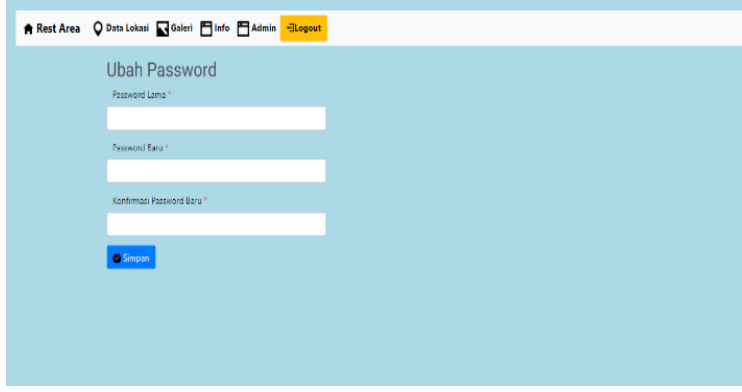

Gambar 16. Tampilan Ubah Sandi Admin

\section{B. PEMBAHASAN}

Setelah aplikasi selesai dikerjakan selanjutnya dilakukan pengujian aplikasi. Selain pengujian fungsional dilakukan juga pengujian responden. Berikut beberapa pengujian yang dilakukan.

1. Pengujian Sistem

Pengujian sistem dilakukan untuk menjamin berjalannya aplikasi dengan baik. Dengan adanya pengujian ini juga bisa mengetahui kelemahan dari sistem ini. Sehingga, jika terdapat kesalahan dari sistem dapat dilakukan perbaikan. Pada pengujian ini digunakan metode black box dan kuisioner.

a. Pengujian Black Box

Hasil dari pengujian black box adalah sebagai berikut:

1) Pengujian halaman Login Admin

Pengujian pada halaman ini dilakukan untuk mengetahui apakah sistemnya sudah berjalan dengan baik sesuai dengan program yang dibuat. Hasil pengujian halaman login admin ini dapat dilihat pada

tabel

6.

Tabel 6. Hasil Pengujian Halaman Login Admin

\begin{tabular}{|c|c|c|c|}
\hline No & Pengujian & $\begin{array}{l}\text { Keluaran yang } \\
\text { dihasilkan }\end{array}$ & Status \\
\hline 1. & $\begin{array}{l}\text { Tampilan } \\
\text { halaman login }\end{array}$ & $\begin{array}{l}\text { Menampilkan } \\
\text { halaman login } \\
\text { degan tampilan } \\
\text { munculnya form } \\
\text { username dan } \\
\text { password }\end{array}$ & Baik \\
\hline 2. & Akses login & $\begin{array}{l}\text { Mendapatkan hak } \\
\text { untuk mengakses } \\
\text { data setelah } \\
\text { memasukkan } \\
\text { username dan } \\
\text { password }\end{array}$ & Baik \\
\hline
\end{tabular}

2) Pengujian halaman Admin

Pengujian pada halaman ini dilakukan untuk mengetahui apakah proses-proses yang ada pada halaman ini sudah berjalan dengan baik sesuai dengan program yang telah. Terdapat skenario pengujian yang dapat dilihat pada tabel 7 . 
Tabel 7. Hasil Pengujian Halaman Admin

\begin{tabular}{|c|c|c|c|}
\hline No & Pengujian & $\begin{array}{l}\text { Keluaran yang } \\
\text { dihasilkan }\end{array}$ & Status \\
\hline 1 & Button Tambah & $\begin{array}{l}\text { Admin dapat } \\
\text { menambahkan } \\
\text { data lokasi rest } \\
\text { area dan data } \\
\text { gambar lokasi rest } \\
\text { area }\end{array}$ & Baik \\
\hline 2 & Button Hapus & $\begin{array}{l}\text { Admin dapat } \\
\text { menghapus data } \\
\text { lokasi rest area } \\
\text { dan data gambar } \\
\text { lokasi rest area }\end{array}$ & Baik \\
\hline 3 & Button Edit & $\begin{array}{l}\text { Admin dapat } \\
\text { menghapus data } \\
\text { lokasi rest area } \\
\text { dan data gambar } \\
\text { lokasi rest area }\end{array}$ & Baik \\
\hline 4 & $\begin{array}{l}\text { Menambahkan } \\
\text { Foto }\end{array}$ & $\begin{array}{l}\text { Admin dapat } \\
\text { menambahkan } \\
\text { data berupa foto } \\
\text { lokasi rest area }\end{array}$ & Baik \\
\hline 5 & $\begin{array}{l}\text { Mencari Lokasi } \\
\text { Rest Area } \\
\text { Berdasarkan } \\
\text { Nama Tempat, } \\
\text { Alamat, } \\
\text { Fasilitas dan } \\
\text { Kategori }\end{array}$ & $\begin{array}{l}\text { Admin dapat } \\
\text { mencari lokasi rest } \\
\text { area yang diingin } \\
\text { dicari dengan } \\
\text { menuliskan nama } \\
\text { tempat, alamat, } \\
\text { fasilitas dan } \\
\text { kategori }\end{array}$ & Baik \\
\hline 6 & $\begin{array}{l}\text { Mengubah } \\
\text { Password }\end{array}$ & \begin{tabular}{lr}
\multicolumn{1}{r}{ Admin } & dapat \\
mengubah & \\
password & untuk \\
masuk & ke \\
pengolahan & data \\
pada aplikasi &
\end{tabular} & Baik \\
\hline
\end{tabular}

\section{3) Pengujian Halaman Peta}

Pengujian pada halaman ini dilakukan untuk menguji tampilan dan proses-proses yang ada di dalamnya apakah sudah berfungsi sesuai dengan program yang dibuat. Hasil pengujian halaman peta dapat dilihat pada tabel 9 .

Tabel 8. Hasil Pengujian Halaman Peta

\begin{tabular}{llll}
\hline No & Pengujian & $\begin{array}{l}\text { Keluaran yang } \\
\text { dihasilkan }\end{array}$ & Status \\
\hline 1. & $\begin{array}{l}\text { Menampilkan } \\
\text { Peta }\end{array}$ & $\begin{array}{l}\text { User dapat } \\
\text { melihat lokasi } \\
\text { rest area }\end{array}$ & Baik \\
User & dapat & \\
Mencari & $\begin{array}{l}\text { melihat } \\
\text { perbedaan } \\
\text { Area }\end{array}$ & $\begin{array}{l}\text { marker lokasi } \\
\text { rest area yang }\end{array}$ & \\
& Rest & Baik \\
& &
\end{tabular}

\begin{tabular}{|c|c|c|c|c|}
\hline No & Pengujian & $\begin{array}{l}\text { Keluaran } \\
\text { dihasilkan }\end{array}$ & yang & Status \\
\hline & & $\begin{array}{l}\text { sedang } \\
\text { menurut } \\
\text { kategori } \\
\text { ada } \\
\text { masjid, } \\
\text { dan } \\
\text { makan }\end{array}$ & $\begin{array}{r}\text { dicari } \\
\text { yang } \\
\text { yaitu } \\
\text { SPBU } \\
\text { rumah }\end{array}$ & \\
\hline 3. & $\begin{array}{l}\text { Menampilkan } \\
\text { Detail Lokasi }\end{array}$ & $\begin{array}{l}\text { User } \\
\text { melihat } \\
\text { informasi } \\
\text { tentang } \\
\text { rest area } \\
\text { detail }\end{array}$ & $\begin{array}{l}\text { dapat } \\
\text { lokasi } \\
\text { secara }\end{array}$ & Baik \\
\hline 4. & $\begin{array}{l}\text { Menampilkan } \\
\text { Rute }\end{array}$ & $\begin{array}{l}\text { User } \\
\text { melihat } \\
\text { menuju } \\
\text { yang } \\
\text { dituju }\end{array}$ & $\begin{array}{r}\text { dapat } \\
\text { rute } \\
\text { lokasi } \\
\text { ingin }\end{array}$ & Baik \\
\hline 5. & $\begin{array}{l}\text { Menampilkan } \\
\text { Rute Detail }\end{array}$ & $\begin{array}{l}\text { User } \\
\text { melihat } \\
\text { detail } \\
\text { menuju } \\
\text { lokasi } \\
\text { dituju }\end{array}$ & $\begin{array}{r}\text { dapat } \\
\text { secara } \\
\text { rute } \\
\text { ke } \\
\text { yang }\end{array}$ & Baik \\
\hline
\end{tabular}

b. Hasil Pengujian Responden

Pengujian ini dilakukan dengan memberikan kuisoner pada 39 orang sebagai sample pengguna. Untuk melakukan pengambilan kesimpulan berdasarkan hasil yang didapatkan dari kuisoner, maka diadakan maka diadakan beberapa standar penilaian untuk mengetahui apakah aplikasi sudah dapat diterima dengan baik oleh pengguna atau tidak. Adapun hasil pengujian dapat dilihat pada tabel berikut, Hasil pengujian responden terhadap penggunaan aplikasi dapat dijelaskan pada tabel 10 .

Tabel 9. Hasil Pengujian Responden

\begin{tabular}{|c|c|c|c|c|c|c|}
\hline \multirow{2}{*}{$\begin{array}{l}\mathrm{N} \\
\mathrm{O}\end{array}$} & \multirow{2}{*}{$\begin{array}{c}\text { Pertanya } \\
\text { an }\end{array}$} & \multicolumn{5}{|c|}{ Nilai } \\
\hline & & SS & $S$ & $\mathrm{CS}$ & $\mathrm{TS}$ & STS \\
\hline 1. & $\begin{array}{l}\text { Apakah } \\
\text { aplikasi } \\
\text { ini } \\
\text { memilik } \\
\text { i } \\
\text { tampilan } \\
\text { yang } \\
\text { menarik } \\
\text { ? }\end{array}$ & $\begin{array}{c}(19) \\
48,7 \%\end{array}$ & $\begin{array}{c}(19) \\
48,7 \%\end{array}$ & $\begin{array}{c}(1) \\
2,6 \%\end{array}$ & $\begin{array}{l}(0) \\
0 \%\end{array}$ & $\begin{array}{l}(0) \\
0 \%\end{array}$ \\
\hline 2. & $\begin{array}{l}\text { apakah } \\
\text { anda } \\
\text { tertarik } \\
\text { untuk } \\
\text { menggu } \\
\text { nakan } \\
\text { aplikasi } \\
\text { ini? }\end{array}$ & $\begin{array}{c}(10) \\
25,6 \%\end{array}$ & $\begin{array}{l}(23) \\
59 \%\end{array}$ & $\begin{array}{c}(6) \\
15,4 \%\end{array}$ & $\begin{array}{l}(0) \\
0 \%\end{array}$ & $\begin{array}{l}(0) \\
0 \%\end{array}$ \\
\hline
\end{tabular}


Naro, dkk., Sistem Informasi Geografis Pemetaan Titik Rest Area pada Jalan Poros Jalur Samarinda - Penajam Paser Utara Berbasis Web

\begin{tabular}{|c|c|c|c|c|c|c|}
\hline \multirow{2}{*}{$\begin{array}{l}\mathrm{N} \\
\mathrm{O}\end{array}$} & \multirow{2}{*}{$\begin{array}{c}\text { Pertanya } \\
\text { an }\end{array}$} & \multicolumn{5}{|c|}{ Nilai } \\
\hline & & SS & $S$ & CS & TS & STS \\
\hline 3. & $\begin{array}{l}\text { apakah } \\
\text { tombol } \\
\text { pada } \\
\text { aplikasi } \\
\text { ini } \\
\text { berfungs } \\
\text { i dengan } \\
\text { baik? }\end{array}$ & $\begin{array}{c}(15) \\
38,5 \%\end{array}$ & $\begin{array}{c}(22) \\
56,4 \%\end{array}$ & $\begin{array}{c}(2) \\
5,1 \%\end{array}$ & $\begin{array}{l}(0) \\
0 \%\end{array}$ & $\begin{array}{l}(0) \\
0 \%\end{array}$ \\
\hline 4. & $\begin{array}{l}\text { Apakah } \\
\text { aplikasi } \\
\text { ini } \\
\text { mudah } \\
\text { digunak } \\
\text { an? }\end{array}$ & $\begin{array}{l}(16) \\
41 \%\end{array}$ & $\begin{array}{c}(20) \\
51,3 \%\end{array}$ & $\begin{array}{c}(3) \\
7,7 \%\end{array}$ & $\begin{array}{l}(0) \\
0 \%\end{array}$ & $\begin{array}{l}(0) \\
0 \%\end{array}$ \\
\hline 5. & $\begin{array}{l}\text { apakah } \\
\text { desain } \\
\text { halam } \\
\text { pada } \\
\text { aplikasi } \\
\text { ini } \\
\text { sudah } \\
\text { baik? }\end{array}$ & $\begin{array}{c}(12) \\
30,8 \%\end{array}$ & $\begin{array}{c}(22) \\
56,4 \%\end{array}$ & $\begin{array}{c}(5) \\
12,5 \%\end{array}$ & $\begin{array}{l}(0) \\
0 \%\end{array}$ & $\begin{array}{l}(0) \\
0 \%\end{array}$ \\
\hline 6. & $\begin{array}{l}\text { Apakah } \\
\text { aplikasi } \\
\text { ini } \\
\text { sesaui } \\
\text { dengan } \\
\text { kebutuh } \\
\text { an? }\end{array}$ & $\begin{array}{c}(12) \\
30,8 \%\end{array}$ & $\begin{array}{l}(23) \\
59 \%\end{array}$ & $\begin{array}{c}(4) \\
10,3 \%\end{array}$ & $\begin{array}{l}(0) \\
0 \%\end{array}$ & $\begin{array}{l}(0) \\
0 \%\end{array}$ \\
\hline 7. & $\begin{array}{l}\text { Apakah } \\
\text { fitur - } \\
\text { fitur } \\
\text { pada } \\
\text { aplikasi } \\
\text { ini } \\
\text { sudah } \\
\text { jelas? }\end{array}$ & $\begin{array}{c}(14) \\
35,9 \%\end{array}$ & $\begin{array}{c}(17) \\
43,6 \%\end{array}$ & $\begin{array}{c}(2) \\
6,5 \%\end{array}$ & $\begin{array}{l}(0) \\
0 \%\end{array}$ & $\begin{array}{l}(0) \\
0 \%\end{array}$ \\
\hline 8. & $\begin{array}{l}\text { Apakah } \\
\text { aplikasi } \\
\text { ini } \\
\text { memban } \\
\text { tu dalam } \\
\text { pencaria } \\
\text { n lokasi } \\
\text { rest } \\
\text { area? }\end{array}$ & $\begin{array}{c}(15) \\
38,5 \%\end{array}$ & $\begin{array}{c}(22) \\
56,4 \%\end{array}$ & $\begin{array}{c}(2) \\
5,1 \%\end{array}$ & $\begin{array}{l}(0) \\
0 \%\end{array}$ & $\begin{array}{l}(0) \\
0 \%\end{array}$ \\
\hline 9. & $\begin{array}{l}\text { Apakah } \\
\text { informa } \\
\text { si rest } \\
\text { area } \\
\text { pada } \\
\text { aplikasi } \\
\text { ini } \\
\text { sudah } \\
\text { lengkap } \\
\text { ? }\end{array}$ & $\begin{array}{c}(10) \\
25,6 \%\end{array}$ & $\begin{array}{c}(22) \\
56,4 \%\end{array}$ & $\begin{array}{c}(7) \\
17,9 \%\end{array}$ & $\begin{array}{l}(0) \\
0 \%\end{array}$ & $\begin{array}{l}(0) \\
0 \%\end{array}$ \\
\hline 10. & $\begin{array}{l}\text { Apakah } \\
\text { informa } \\
\text { si rute } \\
\text { menuju }\end{array}$ & $\begin{array}{c}(14) \\
35,9 \%\end{array}$ & $\begin{array}{c}(24) \\
61,5 \%\end{array}$ & $\begin{array}{c}(1) \\
2,6 \%\end{array}$ & $\begin{array}{l}(0) \\
0 \%\end{array}$ & $\begin{array}{l}(0) \\
0 \%\end{array}$ \\
\hline
\end{tabular}

\begin{tabular}{|c|c|c|c|c|c|c|}
\hline \multirow{2}{*}{$\begin{array}{l}\mathrm{N} \\
\mathrm{O}\end{array}$} & \multirow{2}{*}{$\begin{array}{c}\text { Pertanya } \\
\text { an }\end{array}$} & \multicolumn{5}{|c|}{ Nilai } \\
\hline & & SS & $S$ & CS & TS & STS \\
\hline & \multicolumn{6}{|l|}{ rest } \\
\hline & \multicolumn{6}{|l|}{ area } \\
\hline & \multicolumn{6}{|l|}{ yang } \\
\hline & \multicolumn{6}{|l|}{ ada } \\
\hline & \multicolumn{6}{|l|}{ pada } \\
\hline & \multicolumn{6}{|l|}{ rest } \\
\hline & \multirow{2}{*}{\multicolumn{6}{|c|}{$\begin{array}{l}\text { area di } \\
\text { aplikasi }\end{array}$}} \\
\hline & & & & & & \\
\hline & \multicolumn{6}{|l|}{ ini } \\
\hline & \multicolumn{6}{|l|}{ memban } \\
\hline & & & & & & \\
\hline
\end{tabular}

Berdasarkan hasil kuisoner di atas, diketahui bahwa aplikasi ini sudah dapat berjalan dengan baik. Menggunakan rumus persentase, maka dapat disimpulkan bahwa aplikasi sudah sangat baik dari segi tampilan dan manfaat.

\section{KESIMPULAN}

Pada pembuatan aplikasi Sistem Informasi Geografis Pemetaan Titik Rest Area Pada Jalan Poros Jalur Samarinda - Penajam Paser Utara diperoleh data titik rest area sebanyak 58 titik yang terdiri 27 masjid, 28 rumah makan dan 3 SPBU yang tersebar sepanjang jalan poros jalur Samarinda menuju Penajam Paser Utara. Dari hasil tangapan responden mengenai uji coba pada aplikasi memiliki nilai tertinggi untuk jawaban Setuju (S) pada 10 pertanyaan yang diajukan. Aplikasi ini dapat dikembangkan ke versi mobile, agar lebih mudah diakses.

\section{REFERENSI}

[1] H. Yanto, "Sistem Informasi Geografis Tempat Peribadatan Wilayah Kota Padang Berbasis Web," Majalah Ilmiah, Vol. 24, No. 2, pp. 267-273, 2017.

[2] K. S. Pejabat Pengelola Informasi dan Dokumentasi, Keadaan Umum Kota Saamarinda, Samarinda: Rencana Terpadu Program Investasi Infrastruktur Jangka Menengah (RPI2JM)., 2019.

[3] P. K. PPU, Buku Putih Sanitasi Kabupaten Penajam Paser Utara 2013 Percepatan Pembangunan Sanitasi Pemukiman (PPSP), Kab. Penajam Paser Utara: Percepatan Pembangunan Sanitasi Pemukiman (PPSP), 2013.

[4] E. Prahasta, Sistem Informasi Geografis: Konsep-konsep Dasar Prespektif Geodesi \& Geomatika, Bandung: Informatika, 2015.

[5] D. and M. N. , Fundamentals For Geographic Information, USA: John Wiley \& Sons Inc.,, 2003.

[6] D. N. Michae, FUNDAMENTALS FOR GEOGRAPHIC INFORMATION, USA: John Wiley \& Sons Inc.,, 2003. 
JUST TI: (Jurnal Sains Terapan Teknologi Informasi) 13, Januari, 2021: 29-36

ISSN: 2579-4510(online) ISSN: 2085-6458(print)

[7] E. Edwar, H. Budiarto and A. Fitriansyah, "Sistem Informasi Geografis Lokasi Tempat Ibadah Di Denpasar Berbasis Mobile," Vol 2 No 2 (2013): Jurnal Eksplora Informatika, pp. 169-180, 2016.

[8] A. P. Wijaya, A. Suprayogi and M. S. Gustavianto, "Aplikasi Sistem Informasi Goegrafis (SIG) Persebaran Usaha Mikro kecil Menengah (UMKM) Berbasis Web (Studi Kasus : Kota Salatiga)," Jurnal Geodesi Undip Volume 5, Nomor 1, Tahun 2016, (ISSN : 2337-845X), pp. 49-56, 2016.

[9] S. M. Zulkarnain, B. Sudarsono and A. L. Nugraha, "Pemanfaatan Webgis untuk Pemetaan Persebaran SPBU di Kota Semarang," Jurnal Geodesi Undip Volume 4, Nomor 3, Tahun 2014, (ISSN : 2337-845X), pp. 19-25, 2015.

[10] T. A. Utomo, B. D. Yuwono and F. J. Amarrohman , "Aplikasi Sistem Informasi Geografis Berbasis Web dan Android untuk Pemilihan Jalur Alternatif Menuju Tempat Pariwisata (Studi Kasus: Kota Wisata Cibubur dan Jungleland, Kabupaten Bogor)," Jurnal Geodesi Undip Volume 6, Nomor 2, Tahun 2017, (ISSN : 2337-845X), pp. $1-11,2017$.

[11] S. Karim et al., "Sistem Informasi Geografis Pengelolaan Daerah Aliran Sungai ( Das ),” pp. 51-59, 2019.

[12] M. Z. Rohman, Irwansyah, and W. E. Sari, "The Medical Facilities Selection Based on Location-Based Services Application Using SAW and TOPSIS Algorithm," J. Phys. Conf. Ser., vol. 1577, no. 1, 2020, doi: 10.1088/17426596/1577/1/012012. 